\title{
The minor intrusions of Assynt, NW Scotland: early development of magmatism along the Caledonian Front
}

\author{
K. M. Goodenough ${ }^{1, *}$, B. N. Young ${ }^{2,3}$ and I. Parsons ${ }^{4}$ \\ ${ }^{1}$ British Geological Survey, West Mains Road, Edinburgh EH9 3LA, UK \\ 2 Department of Geology and Mineralogy, University of Aberdeen, Marischal College, Broad Street, \\ Aberdeen AB24 3UE, UK \\ ${ }^{3}$ Baker Hughes Inteq, Barclayhill Place, Portlethen, Aberdeen AB12 4PF, UK \\ ${ }^{4}$ Grant Institute of Earth Science, University of Edinburgh, West Mains Road, Edinburgh EH9 3JW, UK
}

\section{ABSTRACT}

The Assynt Culmination of the Moine Thrust Belt, in the northwest Scottish Highlands, contains a variety of Caledonian alkaline and calc-alkaline intrusions that are mostly of Silurian age. These include a significant but little-studied suite of dykes and sills, the Northwest Highlands Minor Intrusion Suite. We describe the structural relationships of these minor intrusions and suggest a classification into seven swarms. The majority of the minor intrusions can be shown to pre-date movement in the Moine Thrust Belt, but some appear to have been intruded during the period of thrusting. A complex history of magmatism is thus recorded within this part of the Moine Thrust Belt. New geochemical data provide evidence of a subduction-related component in the mantle source of the minor intrusions.

Keywords: Assynt, Caledonian, minor intrusion, Moine Thrust, Scotland.

\section{Introduction}

Within the Assynt Culmination of the Moine Thrust Belt of NW Scotland (Fig. 1) lie a variety of Caledonian alkaline and calc-alkaline intrusions that have been of interest to geologists since the end of the $19^{\text {th }}$ century (e.g. Bonney, 1883; Heddle, 1881; Horne and Teall, 1892; Teall, 1900; Teall, 1907; Shand, 1910; Phemister, 1926). The main syenite intrusions of Assynt, the Loch Borralan and Loch Ailsh plutons, have been well studied (e.g. Parsons, 1965; Woolley, 1970; van Breemen et al., 1979; Thompson and Fowler, 1986, Halliday et al., 1987; Thirlwall and Burnard, 1990; Parsons, 1999). Associated with them is a less well understood suite of minor intrusions, formally known as the Northwest Highlands Minor Intrusion Suite, which includes sills and dykes that range in composition from lamprophyres to peralkaline rhyolites and nepheline-syenites. The intrusions of this suite extend from Loch More,

* E-mail: kmgo@bgs.ac.uk

DOI: $10.1180 / 0026461046840207$ north of Assynt, to the Achall valley near Ullapool, but they are most abundant in the Assynt area. The minor intrusions constitute a significant part of the total volume of igneous rock in the Assynt area, but have been little studied. The first detailed study was that of Sabine (1953) who divided the minor intrusions into six classes and studied their relationships to the regional structure. Subsequent publications on the region (e.g. Parsons, 1979) have generally accepted the detailed work of Sabine; a review of the existing literature is provided by Parsons (1999). The only recent investigation of these intrusions was in a hitherto unpublished thesis (Young, 1989). We present new field, petrographical and geochemical data, on the basis of which we have revised the original classification scheme for the minor intrusions. The relationships between the different swarms and their possible sources are discussed below.

\section{Regional geology}

The Assynt Culmination is the largest and most geologically spectacular window through the 


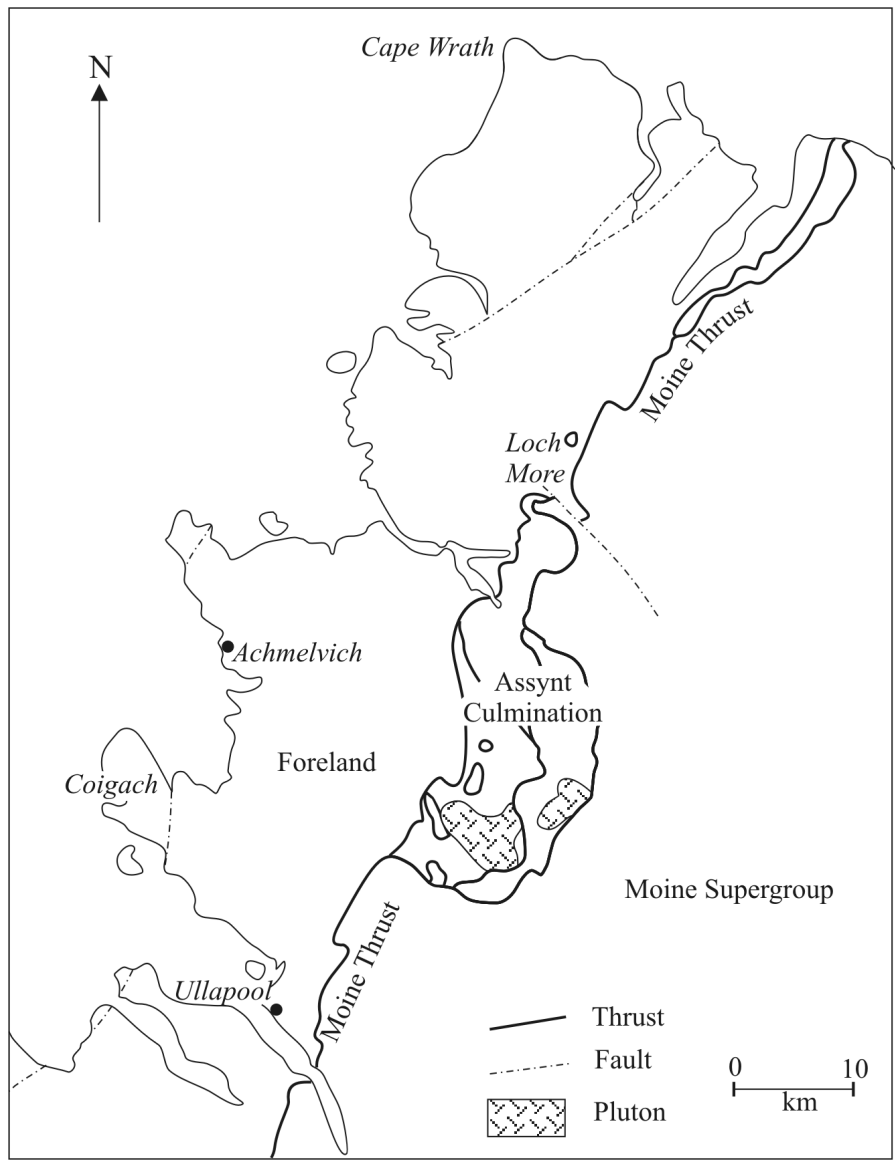

FIG. 1. Simplified map of the northwest of Scotland, showing the major geological structures.

Moine Thrust Belt (Fig. 2) (Johnson and Parsons, 1979; Elliott and Johnson, 1980; Coward, 1983, 1985). West of the Assynt Culmination lies the undisturbed Foreland (Park et al., 2002), where the clastic sedimentary rocks of the Proterozoic Torridonian Supergroup overlie Archaean Lewisian gneisses along an irregular unconformity. The Torridonian rocks are in turn overlain by a Cambro-Ordovician sequence, consisting of thick quartzite units that pass up into fissile mudstones (the Fucoid Beds) and gritty sandstones, with the dolomitic limestones of the Durness Group at the top of the sequence. To the east, the Assynt Culmination is bounded by the Moine Thrust, east of which lie Proterozoic metasedimentary rocks of the Moine Supergroup.

Within the Assynt Culmination, it is generally agreed that three major thrusts can be recognized (Fig. 2), although the exact lines of the thrusts have been disputed (Peach et al., 1907; Bailey, 1935; Sabine, 1953; Krabbendam and Leslie, 2004). Moving west from the Moine Thrust, these are: the Ben More Thrust, with a sheet of Lewisian gneisses, Torridonian sandstones and Cambrian quartzites in its hangingwall; the Glencoul Thrust, carrying Lewisian gneisses and Cambrian quartzites; and the Sole Thrust, carrying duplexes of the Cambro-Ordovician succession. The amount of movement on the Sole Thrust has been a cause of some debate (Coward, 1985; Halliday et al., 1987) and this has not yet been resolved.

The major igneous intrusions in the Assynt region are the alkaline Loch Borralan and Loch Ailsh syenite plutons. The Loch Borralan Pluton is in part silica undersaturated and highly potassic (Woolley, 1970) whereas all units at Loch Ailsh are silica saturated and relatively sodic (Parsons, 

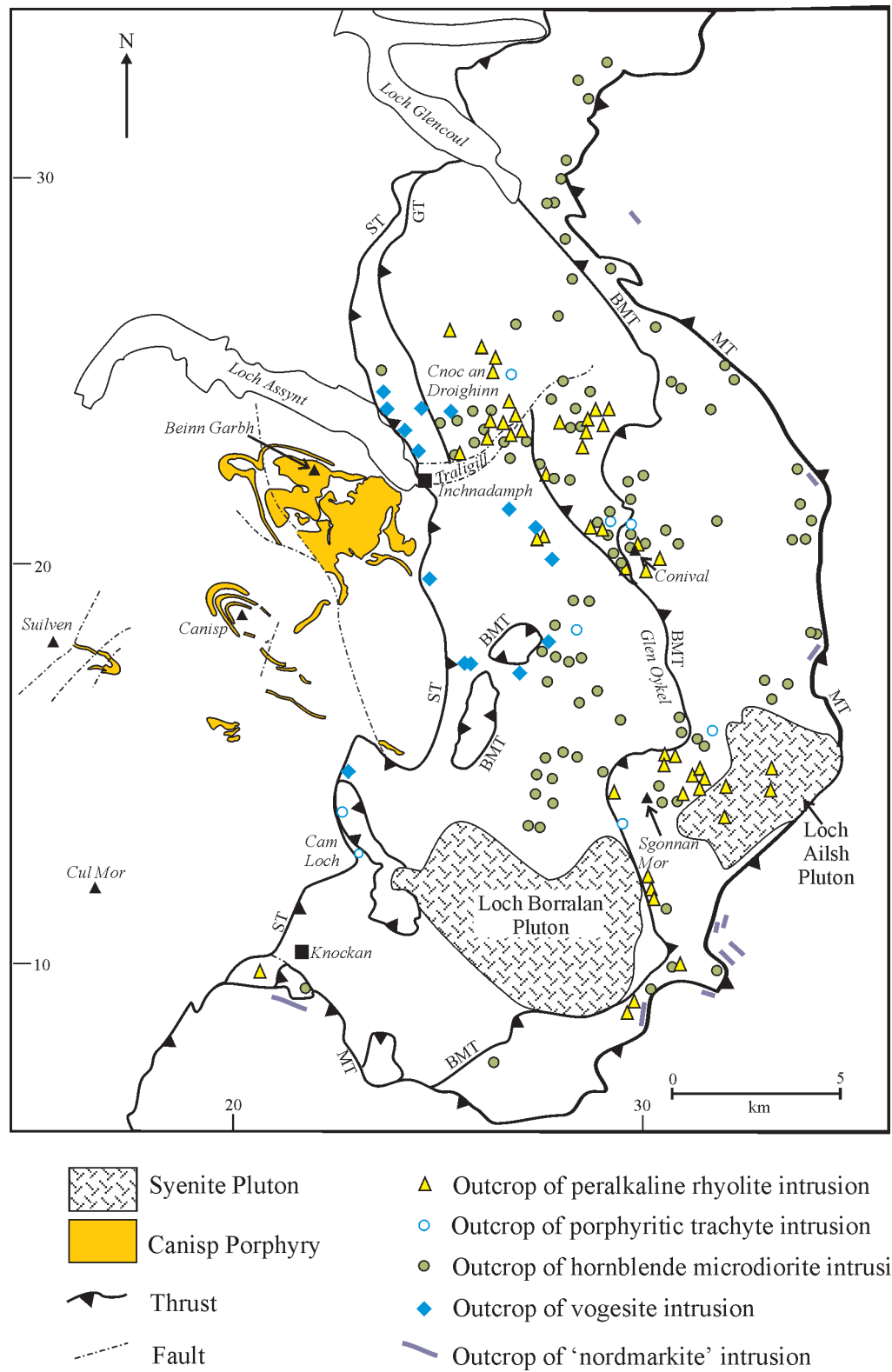

$\Delta$ Outcrop of peralkaline rhyolite intrusion

- Outcrop of porphyritic trachyte intrusion

- Outcrop of hornblende microdiorite intrusion

- Outcrop of vogesite intrusion

Outcrop of 'nordmarkite' intrusion

FIG. 2. Sketch map of the Assynt Culmination, showing the approximate distribution of the main groups of intrusive rocks. Thrust patterns from Peach et al. (1907), modified after Coward (1983) and Krabbendam and Leslie (2004). MT - Moine Thrust; BMT - Ben More Thrust; GT - Glencoul Thrust; ST - Sole Thrust. Locations of minor intrusions from Sabine (1953), modified after Young (1989) and recent BGS mapping. Note that this is not a comprehensive map of all the minor intrusion localities.

1965). Both plutons are Silurian in age: the Loch Borralan Pluton has a U-Pb date of $430 \pm 4 \mathrm{Ma}$ (van Breemen et al., 1979); and the Loch Ailsh Pluton has been dated at $439 \pm 4 \mathrm{Ma}$ (Halliday et al., 1987). The Loch Borralan Pluton is considered to post-date movements on thrusts within the Moine Thrust Belt (Parsons and McKirdy, 1983), whereas the Loch Ailsh Pluton 
TABLE 1. Summary of the modern rock names for the Assynt minor intrusions.

\begin{tabular}{|c|c|c|c|}
\hline $\begin{array}{l}\text { Name given by } \\
\text { Sabine (1953) }\end{array}$ & Modern rock name & $\begin{array}{l}\text { Modern swarm } \\
\text { name }\end{array}$ & $\begin{array}{l}\text { Structural } \\
\text { relationship }\end{array}$ \\
\hline Canisp Porphyry & $\begin{array}{l}\text { Porphyritic quartz- } \\
\text { microsyenite }\end{array}$ & Canisp Porphyry Swarm & $\begin{array}{l}\text { Pre-thrusting in } \\
\text { Moine Thrust Belt }\end{array}$ \\
\hline Ledmorite & $\begin{array}{l}\text { Melanite nepheline- } \\
\text { microsyenite }\end{array}$ & Ledmorite Swarm & Uncertain \\
\hline Grorudite & Peralkaline rhyolite & Peralkaline Rhyolite Swarm & $\begin{array}{l}\text { Pre-thrusting in } \\
\text { Moine Thrust Belt }\end{array}$ \\
\hline $\begin{array}{l}\text { Hornblende- } \\
\text { porphyrite }\end{array}$ & Hornblende microdiorite & Hornblende Microdiorite Swarm & $\begin{array}{l}\text { Pre-thrusting in } \\
\text { Moine Thrust Belt }\end{array}$ \\
\hline Nordmarkite & Quartz-microsyenite & Nordmarkite Swarm & $\begin{array}{l}\text { Predates ductile movement } \\
\text { on Moine Thrust }\end{array}$ \\
\hline Vogesite & Vogesite & Vogesite Swarm & $\begin{array}{l}\text { Pre-thrusting in } \\
\text { Moine Thrust Belt }\end{array}$ \\
\hline Not recognized & Porphyritic trachyte & Porphyritic Trachyte Swarm & $\begin{array}{l}\text { Syn- to post-thrusting } \\
\text { in Moine Thrust Belt }\end{array}$ \\
\hline
\end{tabular}

has generally been considered to pre-date thrusting (Halliday et al., 1987).

\section{Structural relationships of the Assynt minor intrusions}

Sabine (1953) divided the minor intrusions of Assynt into six main classes: 'grorudite'; 'Canisp Porphyry'; 'hornblende porphyrite'; 'nordmarkite porphyry'; 'vogesite' and 'ledmorite'. We have updated this classification on the basis of new field, petrographical and geochemical data (see Table 1 and also Parsons, 1999). New rock names are based on the BGS Rock Classification Scheme Volume 1: Igneous Rocks (Gillespie and Styles, 1999), which is closely based on the IUGS scheme (Le Maitre et al., 1989) and is now used in all BGS maps and publications to ensure consistency. Detailed field mapping has given us a clear understanding of the relationship of the different swarms to each other, and to the regional structures.

\section{Canisp Porphyry}

The Canisp Porphyry is a distinctive red feldsparphyric quartz-microsyenite (Sabine, 1953). It has been recognized only in the Foreland (Fig. 2), close to the Sole Thrust but never east of it, and is generally considered to pre-date movement in the Moine Thrust Belt (e.g. Parsons, 1999). The type area for the Canisp Porphyry is on Beinn Garbh, to the south of Loch Assynt, where it forms a series of sills of which at least one is nearly $50 \mathrm{~m}$ thick.

\section{Vogesites}

The vogesites are green-grey-weathering medium- to coarse-grained hornblende-phyric lamprophyres that form sills up to many tens of metres thick. They occur throughout the Assynt Culmination, but are most common in the Cambro-Ordovician dolomitic limestones of the Sole Thrust Sheet (Fig. 2). They are not seen within the Foreland or east of the Moine Thrust. The best evidence that these intrusions pre-date thrusting can be seen at the roadside on the north shore of Loch Assynt (NC 240239), where an offshoot from a vogesite sill in dolomitic limestone is clearly imbricated. Some vogesite sills in the Loch Ailsh area have been hornfelsed (Young, 1989) by the intrusion of the Loch Ailsh Pluton (439 Ma; Halliday et al., 1987), which they must therefore pre-date. The vogesites are thus considered to be among the earliest intrusions in the Moine Thrust Zone in Assynt.

\section{Hornblende microdiorites}

Sabine's 'hornblende porphyrites' have been renamed hornblende microdiorites (Parsons, 1999). These are medium-grained rocks, which 
can be distinguished from the vogesites in hand specimen by the presence of both feldspar and hornblende phenocrysts. They are remarkably consistent in appearance across the area, commonly forming sills that are mostly only a few metres thick but in places up to tens of metres. The hornblende microdiorites are abundant throughout the Assynt Culmination and, as observed by Sabine (1953), they clearly pre-date thrusting, being folded and deformed at many locations.

\section{Peralkaline rhyolites}

The majority of intrusions belonging to the 'grorudite' class of Sabine (1953) are now classified as peralkaline rhyolites. These intrusions are typically brick-red or green on weathered surfaces. They form sills and dykes, generally only $1 \mathrm{~m}$ thick, although a few thicker intrusions have been recognized. Sabine (1953) considered that the peralkaline rhyolites were restricted to the Glencoul and Ben More thrust sheets, including the klippen of the Ben More Thrust (Fig. 1). However, we have now recognized peralkaline rhyolites in several locations beneath the Ben More Thrust, including examples just above the Sole Thrust at Knockan and at Cam Loch, and within imbricated limestones at Cnoc an Uamh in Glen Traligill. Many of the peralkaline rhyolite intrusions can be clearly shown to pre-date thrusting, since they are deformed by thrust-related folding (e.g. on Cnoc an Droighinn; Coward and Potts, 1985). Peralkaline rhyolite sills cut sills of hornblende microdiorite on the slopes of Cnoc an Droighinn above Inchnadamph, confirming that the peralkaline rhyolites are the youngest of the pre-thrusting minor intrusions. A sill of peralkaline rhyolite is also seen cutting syenites of the Loch Ailsh Pluton in Glen Oykel (Parsons, 1999).

\section{Porphyritic trachytes}

A few intrusions described by Sabine (1953) as grorudites have now been recognized as a distinct group of porphyritic trachytes. These also form brick-red weathering sills and dykes with small feldspar phenocrysts, but are chemically and petrographically distinct from the peralkaline rhyolites. The porphyritic trachytes generally seem to be concentrated close to the Ben More Thrust. At two localities, one on the slopes of Conival and the other below Sgonnan Mor, dykes of porphyritic trachyte cut across foliations that are related to movements on the Ben More Thrust, indicating that the porphyritic trachytes are later intrusions. However, at other localities the porphyritic trachytes may be cut off by late movements along thrusts, although the critical relationships are almost always obscured due to a lack of exposure.

\section{Nordmarkite Swarm}

This suite of intrusions was termed "nordmarkitic rocks" by Sabine (1953) following terminology used by Phemister (1926). Parsons (1999) noted that these sills are in fact porphyritic quartzmicrosyenites, but the name 'Nordmarkite Swarm' is retained here in order to distinguish this group of about eight tectonically deformed sills from other, undeformed quartz-microsyenites in Assynt.

Sabine (1953) noted that the quartz-microsyenites of the Nordmarkite Swarm crop out along, close to, and on both sides of, the Moine Thrust plane. This restricted extent has been taken to suggest that most movement on the Moine Thrust had occurred before these sills were intruded (Parsons, 1999), and that the sills were intruded along the line of the thrust. However, we have recognized some sills of the Nordmarkite Swarm several hundred metres east of the Moine Thrust. Mylonitic fabrics are seen within the margins of the intrusions where they are emplaced into mylonitic Moine rocks, indicating that they must have been intruded prior to some, if not all, of the ductile movements on the Moine Thrust.

\section{Ledmorites}

The ledmorites (melanite augite nepheline-microsyenites) described by Sabine $(1952,1953)$ form a few brick-red, fine-grained dykes cutting rocks of the Foreland on the west coast, at Coigach and Achmelvich. They are believed to be related to the Loch Borralan Pluton (Parsons, 1999). Little new work has been carried out on these intrusions and so they are not included in the following sections.

\section{Petrography}

The petrography of the minor intrusions was described briefly by Sabine (1953). The following section summarizes his work, together with our new observations. 


\section{Canisp Porphyry}

The Canisp Porphyry is characterized by large (up to $15 \mathrm{~mm}$ ) euhedral feldspar phenocrysts in a finegrained groundmass that is composed of alkali feldspar crystals $<0.1 \mathrm{~mm}$ across, micropoikilitically enclosed by quartz plates up to $0.5 \mathrm{~mm}$ in size (Sabine, 1953). Phenocrysts are predominantly sodic plagioclase with rare microperthitic and cryptoperthitic alkali feldspar phenocrysts; some examples of both types have mantles of albite, turbid in places. Some larger phenocrysts are composed of aggregates of several feldspar crystals. Pale green pyroxene phenocrysts are are up to $3 \mathrm{~mm}$ long, euhedral, with diopsidic cores mantled by aegirine-augite rims. Tabular biotite phenocrysts, up to $3 \mathrm{~mm}$ long, are commonly altered to chlorite. Small euhedral phenocrysts of titanite and apatite are seen in some samples.

\section{Vogesites}

The vogesites can be divided into melanocratic and leucocratic varieties, on the basis of the abundance of mafic minerals and the presence or absence of pyroxene. A typical melanocratic vogesite consists of $\sim 50 \%$ mafic minerals in a felsic groundmass, with phenocrysts of both diopsidic pyroxene and hornblende occurring in all samples. The groundmass is composed of an interlocking mass of irregular grains of alkali feldspar, up to $3 \mathrm{~mm}$ across, and commonly turbid. The hornblende phenocrysts vary in size from 1 to $7 \mathrm{~mm}$ in different samples, and are usually subhedral. The pyroxene phenocrysts show variable degrees of alteration; in some samples they form colourless, euhedral crystals up to $1 \mathrm{~mm}$ long, but in many other samples the pyroxenes are represented by clusters of euhedral crystals that have been extensively altered to chlorite-rich aggregates. Calcite is present in all the pyroxene-bearing vogesites, and commonly appears to be replacing primary minerals or forming vein fills.

The leucocratic vogesites contain sparse phenocrysts of hornblende up to $4 \mathrm{~mm}$ long, in a groundmass composed mainly of plates of alkali feldspar. Calcite is absent, as is pyroxene; rare plates of biotite are typically altered to chlorite.

\section{Hornblende microdiorites}

The hornblende microdiorites are strongly porphyritic, with phenocrysts of feldspar and hornblende occurring in a fine-grained feldspathic groundmass (Sabine, 1953). The feldspar phenocrysts include both microperthitic alkali feldspars up to $3 \mathrm{~mm}$, and larger sodic plagioclase crystals. They are typically sericitized, and aggregates of several crystals are common. Many of the crystals show oscillatory or complex sector zoning. Hornblende phenocrysts range in length from 0.5 to $3 \mathrm{~mm}$, and some are zoned. Plates of altered biotite are also present in some samples.

\section{Peralkaline rhyolites}

The peralkaline rhyolites commonly have a finegrained groundmass, with alkali feldspar phenocrysts up to $5 \mathrm{~mm}$ across that are typically turbid and have been largely recrystallized to coarse patch perthite. Fresher examples of these phenocrysts contain areas of lamellar microperthites or are featureless and therefore probably cryptoperthitic, and some are crowded with tiny aligned needles, probably of aegirine. Many phenocrysts appear to be glomerocrysts of irregular alkali feldspar grains and occasional plagioclase, which appears to have been largely replaced. Euhedral phenocrysts of aegirine-augite and titanite are found in some samples. The groundmass consists of fine-grained quartz and feldspar crystals, together with stubby needles of aegirine that commonly define a magmatic flow direction. To the south of Glen Traligill (Fig. 2), the peralkaline rhyolites are petrographically variable. Some coarse-grained examples from Sgonnan Mor have feldspar phenocrysts up to $7 \mathrm{~mm}$ across. Other peralkaline rhyolites from the Sgonnan Mor-Loch Ailsh area contain quartz and/or sodic amphibole phenocrysts. Microprobe analyses show that the range of pyroxene compositions in the peralkaline rhyolites is very large, from $\mathrm{Ac}_{10} \mathrm{Di}_{75} \mathrm{Hd}_{15}$ to nearly pure aegirine (Young, 1989).

\section{Porphyritic trachytes}

The porphyritic trachytes contain phenocrysts of sodic plagioclase up to $7 \mathrm{~mm}$ long, in a finegrained groundmass that consists almost entirely of aligned laths of alkali feldspar. Unaltered mafic silicate phenocrysts have not been recognized, but irregular aggregates of opaque oxides may represent pseudomorphs of original mafic phases.

\section{Nordmarkite Swarm}

The rocks of the Nordmarkite Swarm are medium- to coarse-grained quartz-microsyenites, 
with phenocrysts of turbid alkali feldspar (largely perthitic, but also including discrete sub-crystals of microcline and albite) in a medium-grained groundmass. The phenocrysts are in places up to $5 \mathrm{~mm}$ long, but are more commonly $1-2 \mathrm{~mm}$, and in places show signs of strain such as kinked twins. Small (up to $1 \mathrm{~mm}$ ) phenocrysts of clinopyroxene (augite) are also seen in some samples. The groundmass typically consists of quartz and feldspar with epidote, biotite, chlorite and calcite, plus accessory zircon and sulphides. A distinctive feature of many of the samples of the Nordmarkite Swarm, particularly those from the margins of sills within mylonites just above the Moine Thrust, is that the groundmass shows a strong penetrative tectonic fabric. In comparison with undeformed parts of the sills, the crystals within the groundmass in deformed samples have undergone a pronounced grain-size reduction, to about a half or a third of their original size. In many deformed samples the fabric wraps the alkali feldspar phenocrysts in an asymmetrical manner, and strain-shadows filled by quartz occur adjacent to some alkali feldspar phenocrysts. This shear fabric is in places cut across by later calcite veins. In general, the fabric in the sheared quartzmicrosyenites indicates that these rocks have undergone significant amounts of ductile deformation together with the surrounding mylonitized Moine country rocks.

\section{Geochemistry}

Bulk-rock samples of most of the different types of minor intrusions, with the exception of the Nordmarkite Swarm, were analysed by X-ray fluorescence (XRF) for major and trace elements at Aberdeen University by Young (1989). Selected further samples of peralkaline rhyolites, porphyritic trachytes and quartz-microsyenites of the Nordmarkite Swarm have been analysed as part of the current BGS Moine Thrust Project. These analyses were carried out by XRF, using the PW2400 spectrometer and standard procedures employed by the UKAS-accredited analytical labs at BGS Keyworth. Major elements were analysed on fused beads and trace elements on pressed powder pellets.

The Assynt minor intrusions range from vogesites with $\mathrm{SiO}_{2}$ contents of $52-60$ wt.\% to peralkaline rhyolites that typically have $\mathrm{SiO}_{2}$ contents in excess of 75 wt.\% (Fig. 3). This is a similar range to that described by Fowler and Henney (1996) for the Ach' Uaine Hybrids, a suite of appinitic minor intrusions within the Moine Supergroup, some $50 \mathrm{~km}$ to the east of Assynt. Total alkalis are from $4-8$ wt. $\%$ in the vogesites and hornblende microdiorites, rising to $8-10 \mathrm{wt} . \%$ in the peralkaline rhyolites and higher in some of the porphyritic trachytes (Fig. 3). In general, the Assynt minor intrusions show a tendency for alkali enrichment with increasing silica content, with a corresponding depletion in $\mathrm{Fe}_{2} \mathrm{O}_{3}, \mathrm{MnO}, \mathrm{MgO}, \mathrm{CaO}$ and $\mathrm{TiO}_{2}$. Although the Assynt minor intrusions have generally been considered to be related to the NW Highlands alkaline plutonic suite, the vogesites and hornblende microdiorites are more strictly calc-alkaline (Fig. 4). The peralkalinity index (molar $\left.\left.\left(\mathrm{Na}_{2} \mathrm{O}+\mathrm{K}_{2} \mathrm{O}\right) / \mathrm{Al}_{2} \mathrm{O}_{3}\right)\right)$ of the peralkaline rhyolites averages about 1 , i.e. some of them are not truly peralkaline, although they do typically have normative acmite.

The trace-element characteristics of the minor intrusions are illustrated on multi-element plots, normalized to primitive mantle (Fig. 5). The vogesites, hornblende microdiorites, Canisp Porphyry sills and intrusions of the Nordmarkite Swarm all have very similar patterns, with a clear $\mathrm{Nb}$ trough and relatively high $\mathrm{Ba}$ and $\mathrm{Sr}$ contents. The porphyritic trachytes and peralkaline rhyolites show a wider range in their trace element patterns. The majority of these more evolved intrusions have substantially lower $\mathrm{Ba}$ and $\mathrm{Sr}$ contents than the more mafic rocks, and do not have such a pronounced trough at $\mathrm{Nb}$. $\mathrm{Zr}$ contents are generally higher, with the peralkaline rhyolites having the highest $\mathrm{Zr}$ values.

\section{Discussion}

Previous authors have considered the minor intrusions of Assynt as a related, cogenetic suite (Sabine, 1953; Parsons, 1999). However, there are significant variations in structural relationships and in geochemistry between the different intrusion swarms, and it is therefore necessary to consider the possibility that more than one magma source may have been present. The nature of the magma source, or sources, and the derivation of the different magma types, are discussed below.

The most primitive of the Assynt Caledonian magmas were those that formed the mafic vogesites, and these are the most likely parental magmas for the rest of the Assynt minor intrusions. These magmas were clearly mantle derived, since they have high contents of $\mathrm{MgO}$ 


\section{K. M. GOODENOUGH ETAL.}

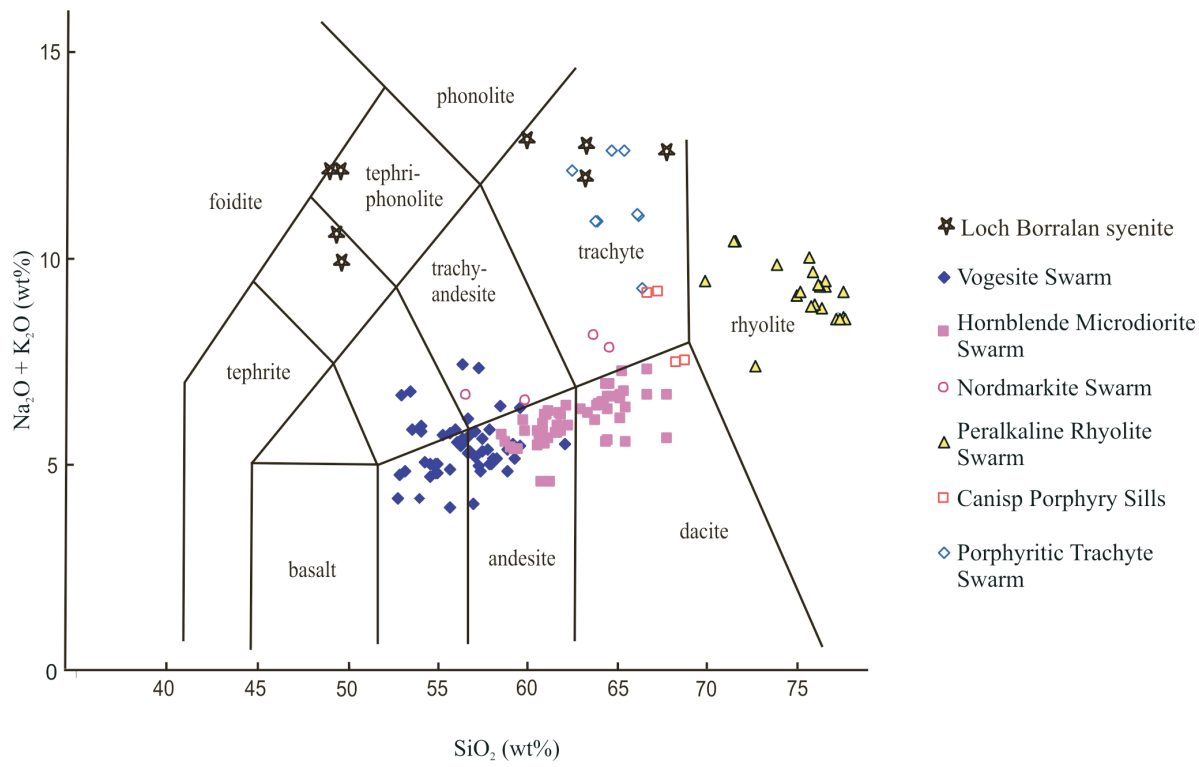

FIG. 3. Total alkalis vs. silica diagram for the Assynt minor intrusions. Data for minor intrusion swarms from Young (1989) and Tables 2 and 3. Data for Loch Borralan syenites from Thirlwall and Burnard (1990). Classification fields from Gillespie and Styles (1999) after Le Bas et al. (1986).

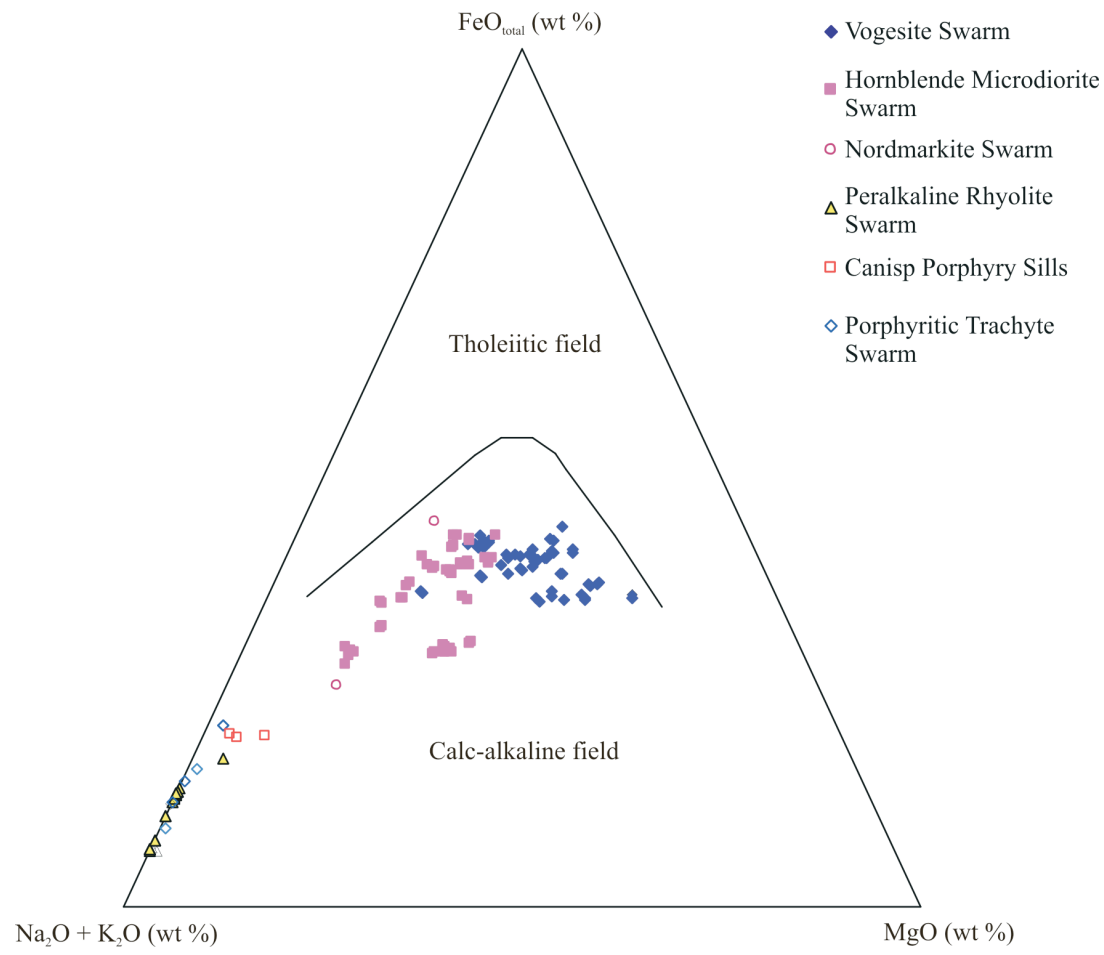

FIG. 4. AFM diagram for the Assynt minor intrusions. Data for minor intrusion swarms from Young (1989) and Tables 2 and 3. Tholeiitic/calc-alkaline division from Irvine and Baragar (1971). 

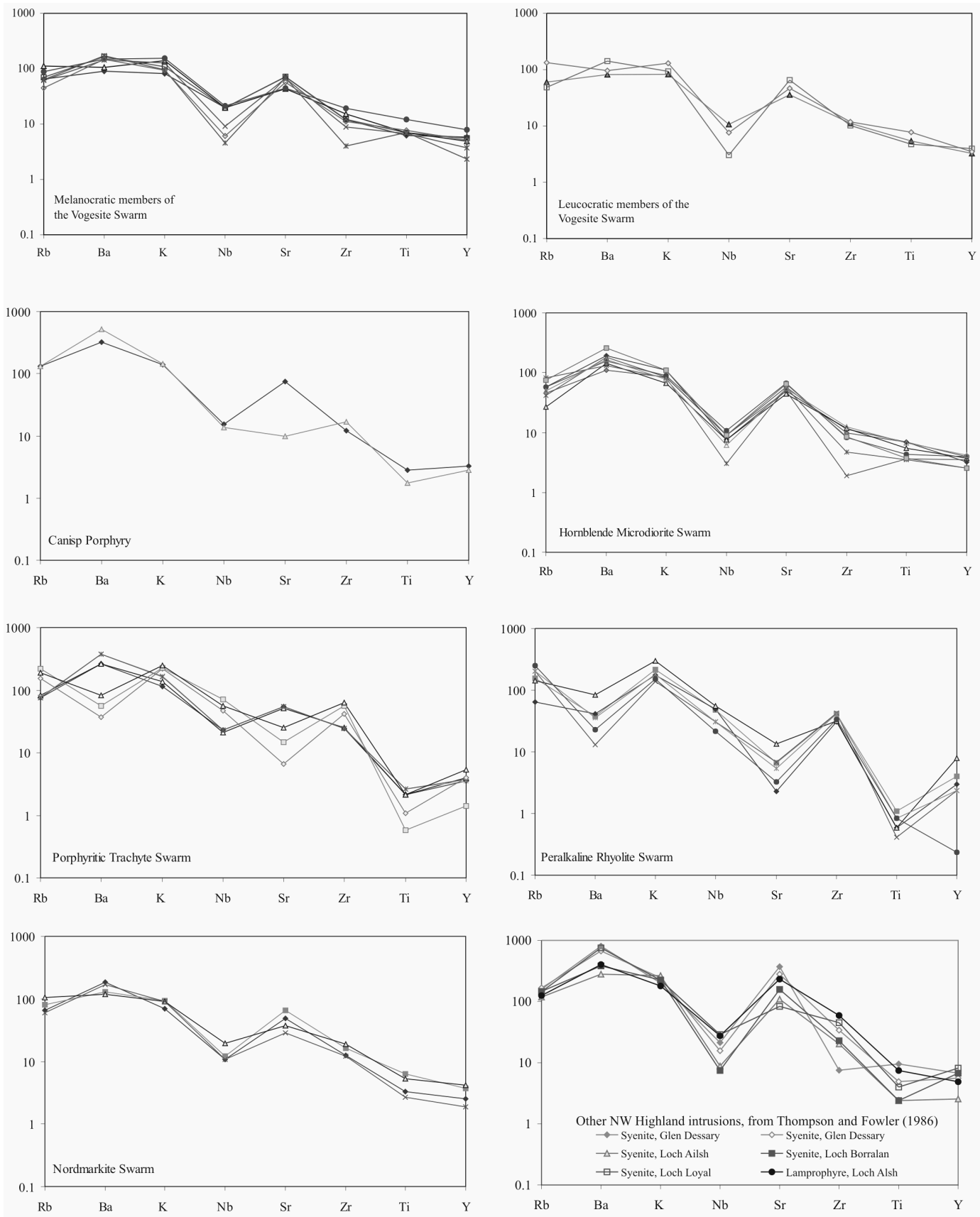

FIG. 5. Multi-element plots, normalized to primitive mantle, for selected samples of the Assynt minor intrusions. Data from Tables 2 and 3 and from Young (1989). Other NW Highland intrusions are shown for comparison; data from Thompson and Fowler (1986). Normalizing values from McDonough and Sun (1995).

(up to $10 \%$ ) and Ni (up to $140 \mathrm{ppm}$, although more typically 50-60).
Major-element modelling experiments, based on the method of Stormer and Nicholls (1978), 
were carried out by Young (1989), and the data are available in that thesis or from the authors. The models can only be taken as approximations, since all the minor intrusions contain phenocrysts and thus rock samples do not necessarily represent true liquid compositions. Young showed that the hornblende microdiorites could have been generated from the same magma that formed the melanocratic vogesites, through simple crystal fractionation of hornblende, plus smaller amounts of diopsidic pyroxene, forsteritic olivine and Fe-Ti oxides. All of these minerals occur as phenocrysts in the vogesites, and the chemical compositions of the main fractionating phases are illustrated together with rock compositions in Fig. 6. The Canisp Porphyry sills are chemically similar to the hornblende microdiorites and could have also formed through fractionation of a vogesite-type parental magma, although there are no vogesite intrusions in the unthrusted Foreland.

Thompson and Fowler (1986) suggested that the peralkaline rhyolites of Assynt were potentially formed through fractionation of alkali feldspar, clinopyroxene, Fe-Ti oxide, apatite, sphene and allanite from the magmas that formed the nearby syenite plutons. However, the peralkaline rhyolites occur throughout Assynt and are not spatially associated with the major syenite bodies. Furthermore, Thompson and Fowler (1986) studied $\mathrm{La} / \mathrm{Nb}$ ratios, which do not vary significantly during fractional crystallization, and showed that the majority of syenites and other Caledonian igneous rocks in the Northern Highlands have very high $\mathrm{La} / \mathrm{Nb}$ ratios $(>5)$. La data are not available for all the types of minor intrusion, but $\mathrm{La} / \mathrm{Nb}$ for the peralkaline rhyolites and porphyritic trachytes ranges from 0.3 to 3.2. Derivation of the peralkaline rhyolites through fractionation of a syenite magma thus seems to be unlikely.

We consider it more likely that the Assynt peralkaline rhyolites formed by extensive crystal fractionation of plagioclase and hornblende from the vogesite and hornblende microdiorite magmas (Fig. 6). The $\mathrm{Ba}$ and $\mathrm{Sr}$ depletion in the peralkaline rhyolites relative to the other minor intrusion suites could be explained by the fractionation of plagioclase from an evolving hornblende microdiorite magma, and the large range of pyroxene compositions (Young, 1989) is consistent with this suggestion. However, evolution through fractional crystallization alone may not explain the distinctly higher $\mathrm{Nb}$ and $\mathrm{Zr}$ contents in the

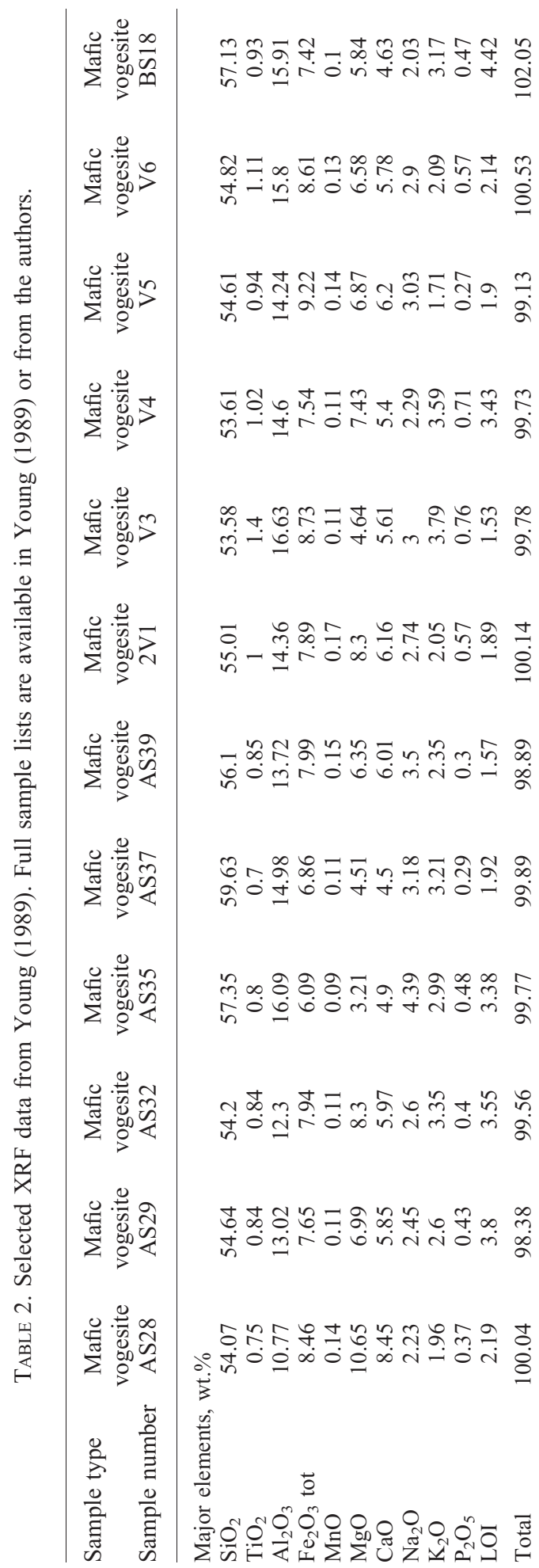




\begin{tabular}{|c|c|c|c|c|}
\hline 士n守守의 & 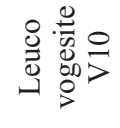 & 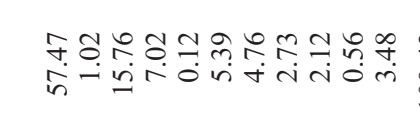 & $\stackrel{\text { f̊. }}{8}$ & 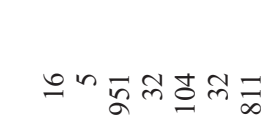 \\
\hline Im $\underset{\substack{\infty \\
\text { I }}}{ }$ & 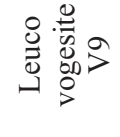 & 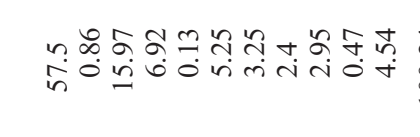 & さ্ড & $\because+\infty \frac{\infty}{\infty} \curvearrowleft \sqrt{n} \frac{0}{\sigma}$ \\
\hline 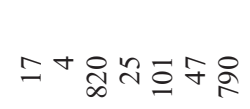 & 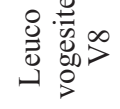 & 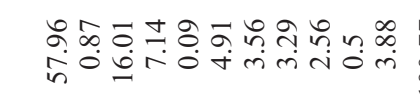 & 尺િ. & In \\
\hline 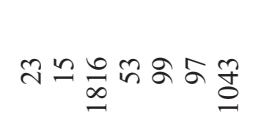 & 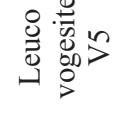 & 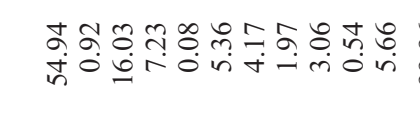 & $\begin{array}{l}\stackrel{2}{a ̆} \\
\text { à }\end{array}$ & 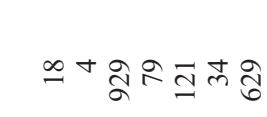 \\
\hline 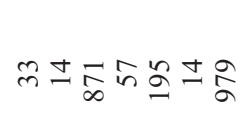 & 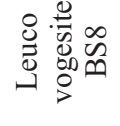 & 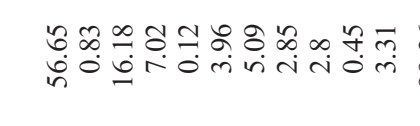 & $\begin{array}{l}\stackrel{\circ}{\mathfrak{a}} \\
\stackrel{2}{a}\end{array}$ & 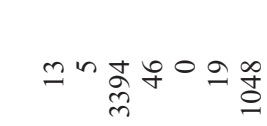 \\
\hline 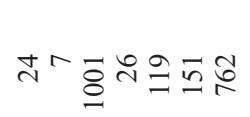 & 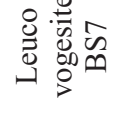 & 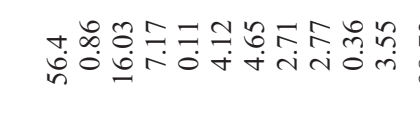 & 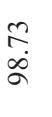 & 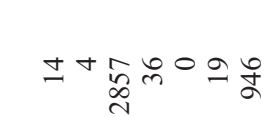 \\
\hline$=m \hat{\sim} \sim m \sim n \cong$ & 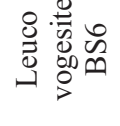 & 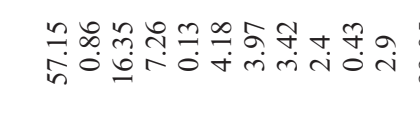 & $\begin{array}{l}\stackrel{2}{a} \\
\stackrel{a}{a}\end{array}$ & 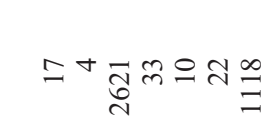 \\
\hline 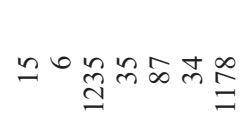 & 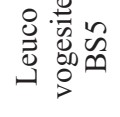 & 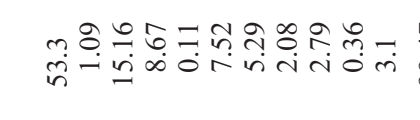 & 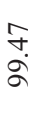 & এnণ্তি \\
\hline$\because \underset{\sim}{\infty} \tilde{m} \sigma \widetilde{\alpha}$ & 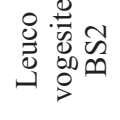 & 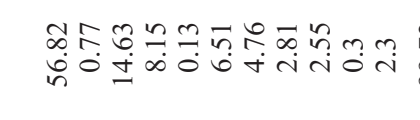 & 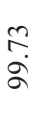 & 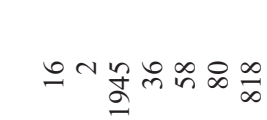 \\
\hline ন & 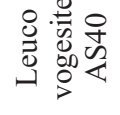 & 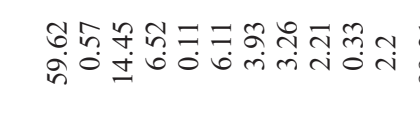 & ๙े & o+ন্তি \\
\hline 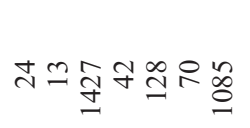 & 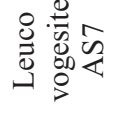 & 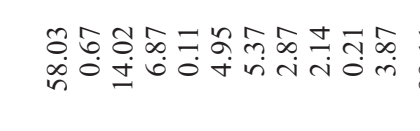 & च̆ & 므윯즈 \\
\hline 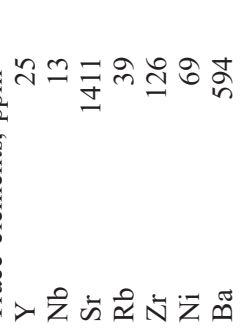 & 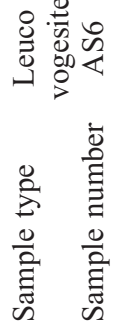 & 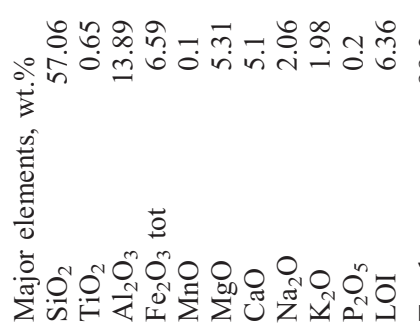 & $\begin{array}{l}\frac{\pi}{0} \\
\stackrel{0}{0}\end{array}$ & 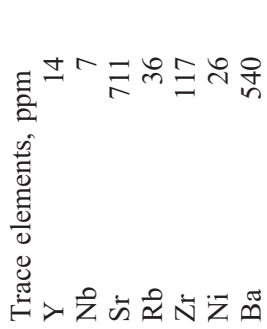 \\
\hline
\end{tabular}


K. M. GOODENOUGH ETAL.

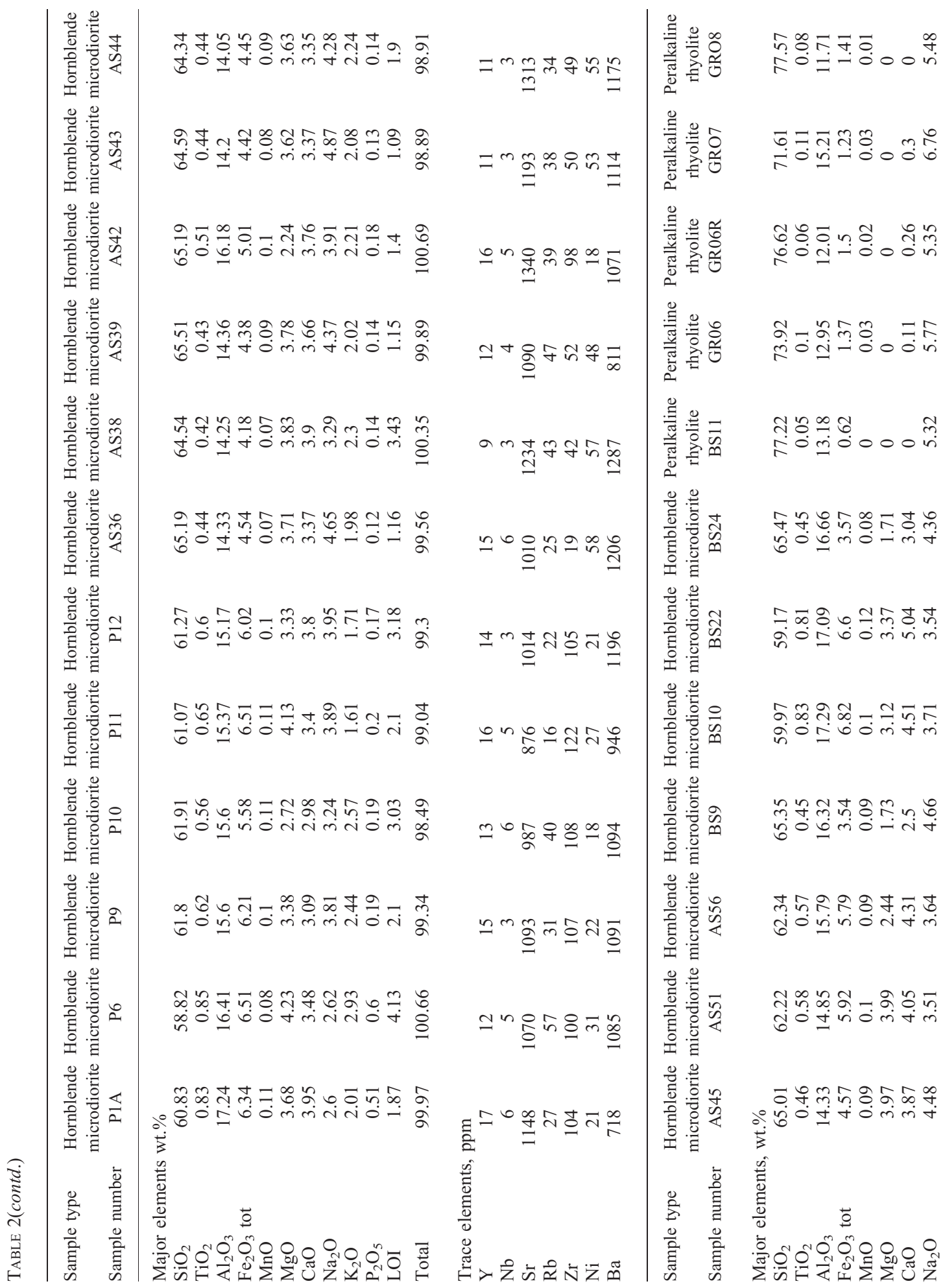




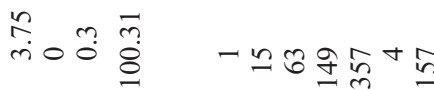

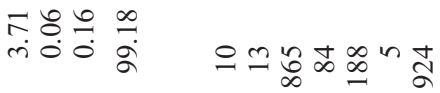

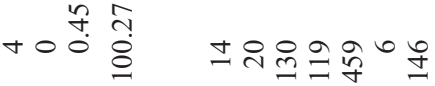

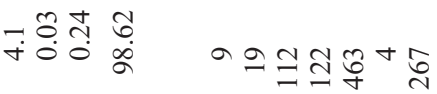

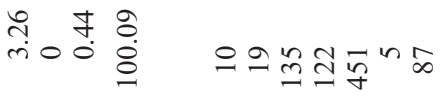

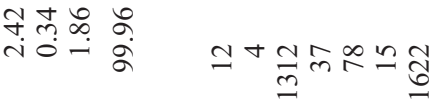

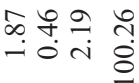

$\stackrel{\infty}{\rightarrow} \curvearrowleft \bar{g}$

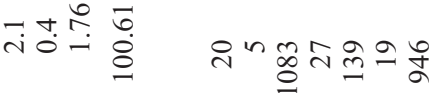

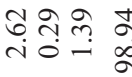

ำกำ

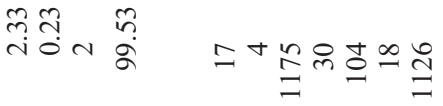

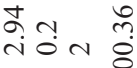

ヘ

กำำ

产ㅇํำ的票

$\frac{0}{\stackrel{0}{0}}$

유윰유

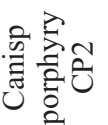

$\infty$ సุळ

क्ष்

그옹워

记

กิ

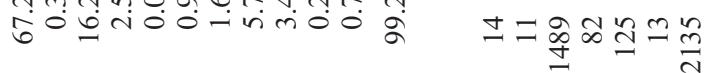

.

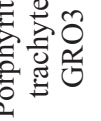

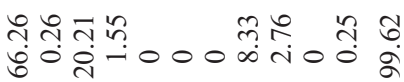

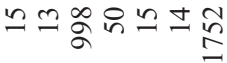

$\stackrel{\Xi}{\Xi} \approx$

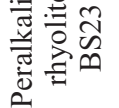

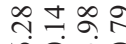

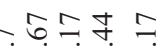

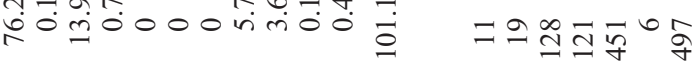

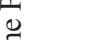

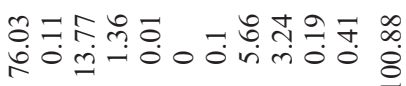

ஓं

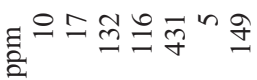

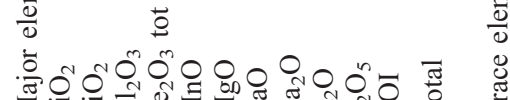

迎 
K. M. GOODENOUGH ETAL.

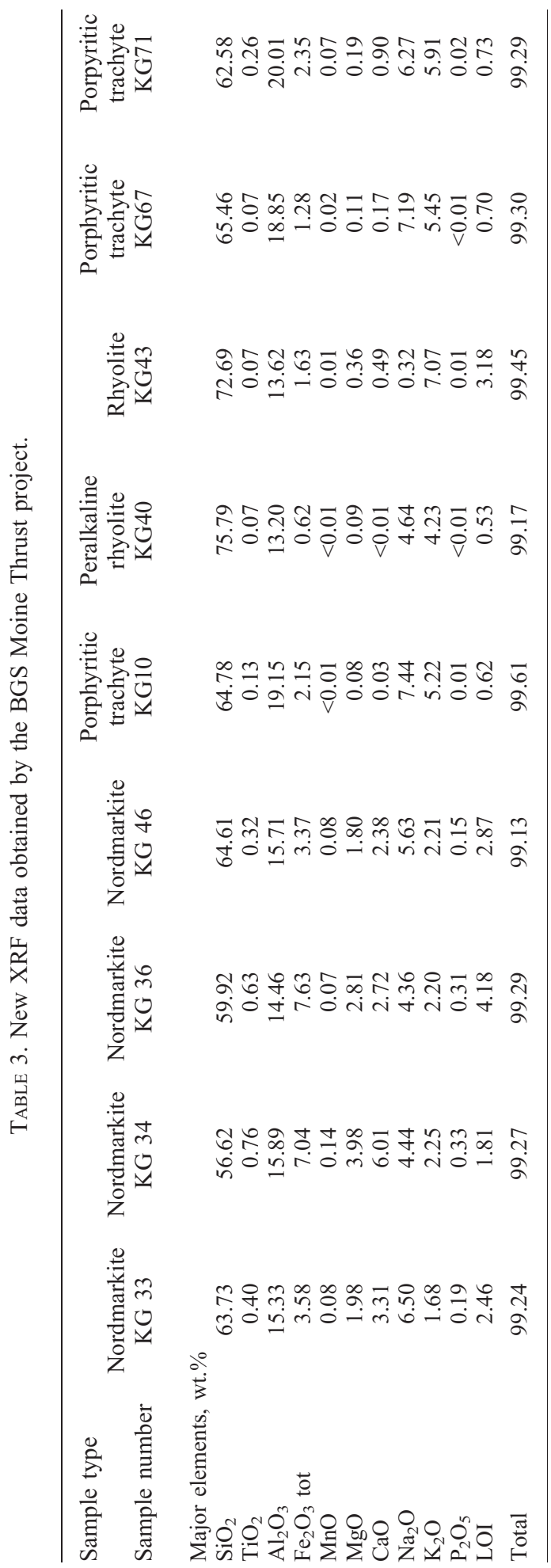

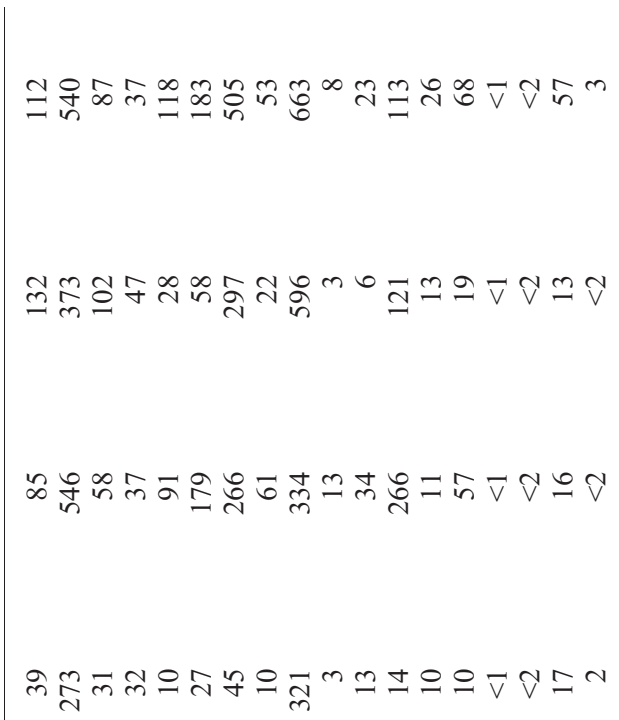

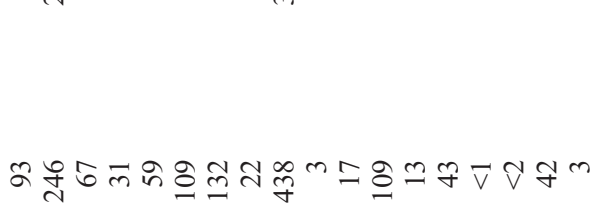

ํㅡㄹ

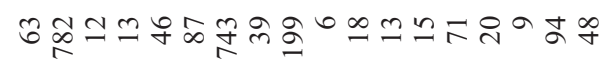

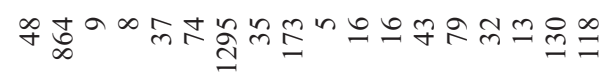

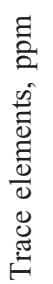

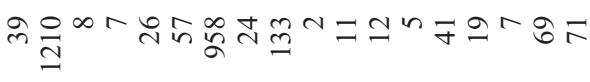

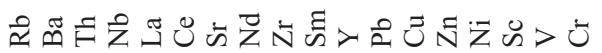


peralkaline rhyolites (Young, 1989). Although the mafic mineralogy of the peralkaline rhyolites is now largely anhydrous, the internal morphology of the feldspar glomerocrysts, with plagioclase apparently having undergone replacement by alkali feldspar, and the presence of very coarse patch perthites, strongly indicates that a residual (peralkaline) fluid phase was associated with the rhyolitic magmas. We suggest that this served to introduce certain incompatible elements, including $\mathrm{Nb}$ and $\mathrm{Zr}$, into the rhyolites.

Since peralkaline rhyolite sills are seen cutting the Loch Ailsh Pluton, which in turn hornfelses sills of vogesite, the evolving magma chamber from which the rhyolites were derived may have existed for a significant period of time. It is clear from field relationships that the vogesite, hornblende microdiorite and peralkaline rhyolite swarms were all emplaced prior to significant movements on the thrusts in the Moine Thrust Belt. The Loch Ailsh Pluton must therefore also pre-date movements on these thrusts.

Alkaline magmatism continued in the area with the emplacement of the strongly alkaline, undersaturated Loch Borralan Pluton after movements on the Ben More and, possibly, the Sole thrusts (see discussion in Parsons, 1999). The porphyritic trachytes are alkali enriched in comparison with members of the Hornblende Microdiorite Swarm that have similar $\mathrm{SiO}_{2}$ contents (Figs 3 and 6).
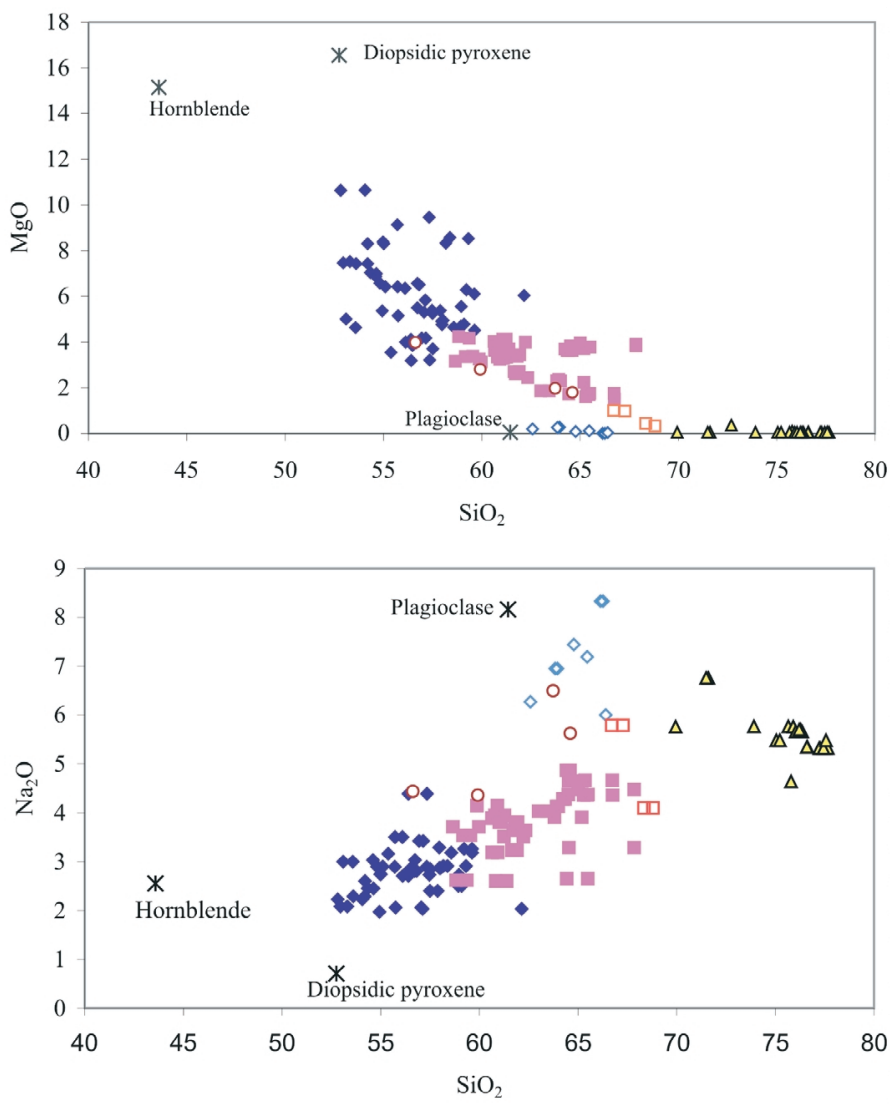

\footnotetext{
- Vogesite Swarm

- Hornblende Microdiorite Swarm

o Nordmarkite Swarm
}

$$
\begin{aligned}
& \Delta \text { Peralkaline Rhyolite Swarm } \\
& \square \text { Canisp Porphyry Sills } \\
& \diamond \text { Porphyritic Trachyte Swarm }
\end{aligned}
$$

Fig. 6. Harker diagrams for the Assynt minor intrusions, including whole-rock analyses from Tables 2 and 3 and Young (1989). Mineral analyses were obtained by electron microprobe studies of samples from the Assynt minor intrusions and were used by Young (1989) in his modelling calculations. 
This may indicate derivation from different parental magmas, albeit possibly with the same primary mantle source. Leucosyenites from the Loch Borralan Pluton are similarly enriched in alkalis (Thirlwall and Burnard, 1990) and plot close to the porphyritic trachytes on the total alkali-silica diagram (Fig. 3). Since both the Porphyritic Trachyte Swarm and the Loch Borralan syenites appear to post-date movement on the Ben More Thrust, it is possible that the porphyritic trachytes represent offshoots of the later syenites of the Loch Borralan Pluton. However, as noted above, the porphyritic trachytes have much lower $\mathrm{La} / \mathrm{Nb}$ ratios than the syenites, so this hypothesis is uncertain.

The quartz-microsyenites of the Nordmarkite Swarm are chemically similar to the hornblende microdiorites, but are moderately alkali enriched. As with the Canisp Porphyry sills, they could theoretically have formed by fractionation of a vogesite-type parental magma. However, it is important to bear in mind that substantial crustal shortening, perhaps as much as $100 \mathrm{~km}$ (Strachan et al., 2002), has occurred between the intrusions of the Nordmarkite Swarm east of the Moine Thrust and the Canisp Porphyry sills of the Foreland. Thus, we prefer to consider the intrusions of the Nordmarkite Swarm as having formed from a separate parental magma, although their chemical similarities to the hornblende microdiorites probably indicate a similar primary mantle source.

Most of the Assynt minor intrusions have $\mathrm{Nb}$ troughs on their multi-element plots and this is generally considered to indicate the presence of subduction-derived material in the mantle source of the magmas, although it is possible that crustal contamination could also produce a $\mathrm{Nb}$ trough. The high $\mathrm{Ba} / \mathrm{Nb}$ ratios of the majority of the Assynt magmas are typically only found in subduction-related settings (Fig. 7). The trace element ratios of the majority of the Assynt minor intrusions, including the vogesites and hornblende microdiorites, are similar to those of many Caledonian igneous rocks across the Northern Highlands. These include other lamprophyres (Canning et al., 1998); members of the appinite suite (Fowler and Henney, 1996); and major syenite plutons (Thompson and Fowler, 1986), and are largely geochemically similar to subduction-related shoshonitic suites (Thompson and Fowler, 1986).

Atherton and Ghani (2002) have related the genesis of the majority of 'Late Caledonian' magmas in Scotland to slab break-off following the Scandian orogeny and the closure of the Iapetus ocean. Although we have shown that the parental magmas for the majority of the Assynt minor intrusions formed prior to, or early during, the main Scandian collisional event, we suggest that the source of the Assynt magmas was influenced by the early stages of Scandian subduction.

The question of why strongly alkaline magmas, including a carbonatite (Young et al., 1994), were emplaced into a region of active crustal shortening, remains an enigma. Ultrapotassic rocks associated with carbonatites are rare outside of continental rift environments, but have also been recorded in Italy, particularly at Mt. Vulture. The tectonic setting of the Mt. Vulture magmatism, close to the Apennine Front, is similar to that of the NW Highlands intrusions. Recent work by Beccaluva et al. (2002) has suggested that the source of these magmas may have been in lithospheric mantle that had undergone an earlier enrichment, possibly due to carbonatitic metasomatism associated with extension, and was then subsequently modified by subduction-related metasomatism. A similar multi-stage process may have generated the source of the alkaline magmas of the NW Highlands.

Further study into the ages and isotopic systematics of the intrusions of the NW Highlands is undoubtedly required in order to fully investigate the sources of these magmas, and hence to understand the processes occurring along the Caledonian Front during the Scandian orogeny (cf. Oliver, 2002).

\section{Conclusions}

We have used field, petrographical and geochemical data to revise the classification of Sabine (1953) for the Assynt minor intrusions, part of the Northwest Highlands Minor Intrusion Suite. We recognize seven swarms of minor intrusions in the Assynt area. The vogesites, hornblende microdiorites, and peralkaline rhyolites all occur within the Assynt Culmination and were emplaced prior to movement on the thrusts within the culmination. The Canisp Porphyry occurs only within the Foreland and is also considered to pre-date thrusting. The intrusions of the Ledmorite Swarm occur only within the Foreland and their relationships to thrust movements are unclear, although the strike of the dykes and their undersaturated character strongly suggest a 


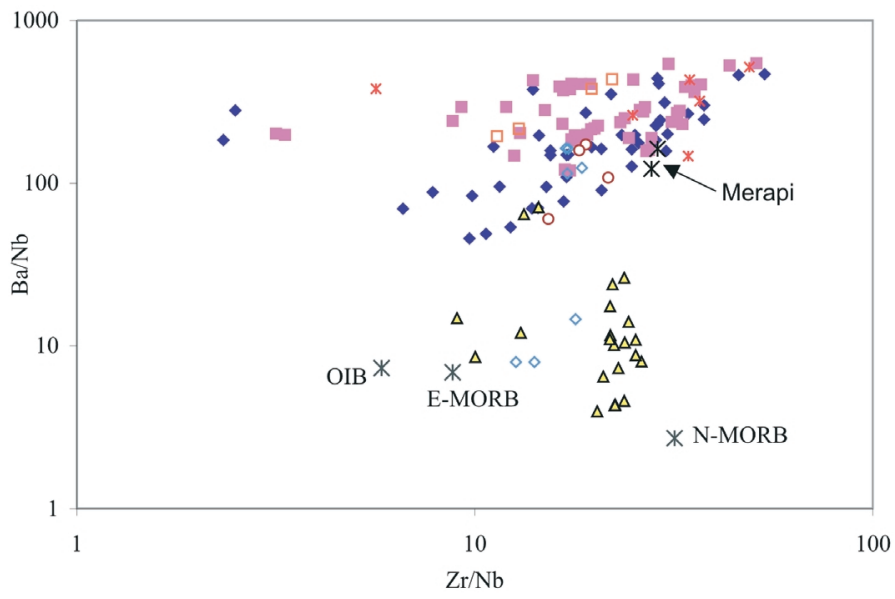

$$
\begin{aligned}
& \text { - Vogesite Swarm } \\
& \text { Hornblende Microdiorite Swarm } \\
& \text { - Nordmarkite Swarm } \\
& \text { * Other NW Highlands intrusions } \\
& \text { (Thompson and Fowler, 1986) }
\end{aligned}
$$

Fig. 7. $\mathrm{Ba} / \mathrm{Nb} v s . \mathrm{Zr} / \mathrm{Nb}$ for the Assynt minor intrusions. Data from Tables 2 and 3 and from Young (1989). Data for other NW Highlands intrusions from Thompson and Fowler (1986) are shown for comparison, together with data from island arc volcanics from Merapi Volcano (Gertisser and Keller, 2003) and for average MORB and OIB (Sun and McDonough, 1989).

direct relationship with the Loch Borralan pluton, which was emplaced after movements on the Ben More Thrust had ceased. The porphyritic trachytes are found within the Assynt Culmination, generally close to the Ben More Thrust, and post-date at least some movement on that thrust. The sills of the Nordmarkite Swarm are found close to the Moine Thrust and were emplaced prior to at least some ductile movement along that thrust.

The mafic vogesites probably represent the closest possible approximation to the parental magmas of the majority of the minor intrusion suite. The hornblende microdiorites were formed by fractional crystallization of this parental magma, and further fractionation generated rhyolitic magmas. These rhyolites were modified by a peralkaline, $\mathrm{Nb}$ and $\mathrm{Zr}$-bearing residual fluid phase following emplacement. The Canisp Porphyry sills and the intrusions of the Nordmarkite Swarm are chemically similar to the hornblende microdiorites, but were spatially separated from them at the time of emplacement, and brought into proximity by crustal shortening. Thus they were not generated in the same magma chamber. Intrusion of all these swarms ceased before the main compressional movements on the thrusts of the Assynt Culmination. The porphyritic trachytes are younger and more alkali-enriched than the other minor intrusions, and may be related to the Loch Borralan Pluton.

On the basis of the available chemical evidence, it appears that the parental magmas for the Northwest Highlands Minor Intrusion Suite were derived from a mantle source that was similar to that postulated for the major intrusions of the NW Highlands, i.e. a mantle source that has been modified by a subductionrelated component (Thompson and Fowler, 1986; Thirlwall and Burnard, 1990). Although the area over which these intrusions were emplaced may have been $>100 \mathrm{~km}$ in extent, it seems likely that all the major and minor intrusions in Assynt were ultimately derived from a similar mantle source. Some magmas generated from this source were emplaced prior to the main movements on the Moine Thrust Zone.

\section{Acknowledgements}

This paper has been written as part of the BGS Moine Thrust Project. Maarten Krabbendam is 
thanked for invaluable discussions of the Assynt minor intrusions and for comments on this manuscript. Much of the work from which this paper is derived was carried out by one of the authors (BY) as a Kilgour-funded PhD studentship at the University of Aberdeen. Mark Ingham, Charles Gowing and Neil Eatherington, BGS Keyworth, are thanked for preparation and analysis of samples for XRF. Peter Sabine is thanked for his advice and assistance, and Sally Gibson is thanked for her constructive review. Sue Loughlin and David Stephenson provided much-appreciated comments on an earlier version of this paper. KMG publishes with the permission of the Executive Director of the British Geological Survey (NERC).

\section{References}

Atherton, M.P. and Ghani, A.A. (2002) Slab breakoff: a model for Caledonian, Late Granite syn-collisional magmatism in the orthotectonic (metamorphic) zone of Scotland and Donegal, Ireland. Lithos, 62, 65-85.

Bailey, E.B. (1935) The Glencoul Nappe and the Assynt Culmination. Geological Magazine, 72, 151-165.

Beccaluva, L., Coltorti, M., Di Girolamo, P., Melluso, L., Milani, L., Morra, V. and Siena, F. (2002) Petrogenesis and evolution of Mt. Vulture alkaline volcanism (Southern Italy). Mineralogy and Petrology, 74, 277-297.

Bonney, T.G. (1883) Notes on a series of rocks from the North-West Highlands collected by C. Callaway, Esq. Quarterly Journal of the Geological Society, 39, 414-422.

Canning, J.C., Henney, P.J., Morrison, M.A., van Calsteren, P.W.C, Gaskarth, J.W. and Swarbrick, A. (1998) The Great Glen Fault: a major vertical lithospheric boundary. Journal of the Geological Society, 155, 425-428.

Coward, M.P. (1983) The thrust and shear zones of the Moine Thrust zone and the NW Scottish Caledonides. Journal of the Geological Society, 140, 795-811.

Coward, M.P. (1985) The thrust structures of southern Assynt, Moine thrust zone. Geological Magazine, 122, 596-607.

Coward, M.P. and Potts, G.J. (1985) Fold nappes: examples from the Moine Thrust zone. Pp. 1147-1158 in: The Caledonide Orogen Scandinavia and Related Areas (D.G. Gee and B.A. Sturt, editors). John Wiley \& Sons Ltd., Chichester, UK.

Elliott, D. and Johnson, M.R.W. (1980) Structural evolution in the northern part of the Moine thrust belt, NW Scotland. Transactions of the Royal Society of Edinburgh: Earth Sciences, 71, 69-96.

Fowler, M.B. and Henney, P.J. (1996) Mixed Caledonian appinite magmas: implications for lamprophyre fractionation and high $\mathrm{Ba}-\mathrm{Sr}$ granite genesis. Contributions to Mineralogy and Petrology, 126, 199-215.

Gertisser, R. and Keller, J. (2003) Trace element and $\mathrm{Nd}, \mathrm{Sr}, \mathrm{Pb}$ and $\mathrm{O}$ isotope variations in medium- $\mathrm{K}$ and high-K volcanic rocks from Merapi Volcano, Central Java, Indonesia: Evidence for the involvement of subducted sediments in Sunda Arc magma genesis. Journal of Petrology, 44, 457-489.

Gillespie, M.R. and Styles, M.T. (1999) BGS Rock Classification Scheme Volume 1. Classification of Igneous Rocks. British Geological Survey Research report ( $2^{\text {nd }}$ edition), RR 99-06. Available at the BGS website http://www.bgs.ac.uk/bgsrcs/

Halliday, A.N., Aftalion, M., Parsons, I., Dickin, A.P and Johnson, M.R.W. (1987) Syn-orogenic alkaline magmatism and its relationship to the Moine Thrust Zone and the thermal state of the lithosphere in NW Scotland. Journal of the Geological Society, 144, 611-617.

Heddle, M.F. (1881) The geognosy and mineralogy of Scotland. Sutherland - Continued. Mineralogical Magazine, 4, 197-254.

Horne, J. and Teall, J.J.H. (1892) On borolanite - an igneous rock intrusive in the Cambrian limestone of Assynt, Sutherlandshire, and the Torridon sandstone of Ross-shire. Transactions of the Royal Society of Edinburgh, 37, 163-178.

Irvine, T.N. and Baragar, W.R.A. (1971) A guide to the chemical classification of the common volcanic rocks. Canadian Journal of Earth Sciences, 8, 523-548.

Johnson, M.R.W. and Parsons, I. (1979) Geological Excursion Guide to the Assynt District of Sutherland. Edinburgh Geological Society, Edinburgh.

Krabbendam, M. and Leslie, A.G. (2004) Lateral ramps and thrust terminations: an example from the Moine Thrust Zone, NW Scotland. Journal of the Geological Society, 161, in press.

Le Bas, M.J., Le Maitre, R.W., Streckeisen, A. and Zanettin, B. (1986) A chemical classification of volcanic rocks based on the total alkali-silica diagram. Journal of Petrology, 27, 745-750.

Le Maitre, R.W. and 11 others (1989) A Classification of Igneous Rocks and Glossary of Terms. Recommendations of the International Union of Geological Sciences Subcommission on the Systematics of Igneous Rocks. Blackwell Scientific Publications, Oxford.

McDonough, W.F. and Sun, S.-S. (1995) The composition of the Earth. Chemical Geology, 120, 223-255.

Oliver, G.J.H. (2002) Chronology and terrane assembly, new and old controversies. Pp. 201-212 in: The 
Geology of Scotland (N.H. Trewin, editor). The Geological Society, London.

Park, R.G, Stewart, A.D. and Wright, D.T. (2002) The Hebridean terrane. Pp 45-80 in: The Geology of Scotland (N.H. Trewin, editor).The Geological Society, London.

Parsons, I. (1965) The feldspathic syenites of the Loch Ailsh intrusion, Assynt, Scotland. Journal of Petrology, 6, 365-394.

Parsons, I. (1979) The Assynt alkaline suite. Pp. 677-681 in: British Caledonides Reviewed (A.L. Harris, C.H. Holland, B.E. Leake, editors). Geological Society of London.

Parsons, I. (1999) Late Ordovician to mid-Silurian alkaline intrusions of the North-west Highlands of Scotland. Pp. 347-393 in: Caledonian Igneous Rocks of Great Britain. (D. Stephenson, R.E. Bevins, D. Millward, A.J. Highton, I. Parsons, P. Stone and W.J. Wadsworth, editors). Geological Conservation Review Series, No. 17. Joint Nature Conservation Committee, Peterborough, UK.

Parsons, I. and McKirdy, A.P. (1983) Inter-relationship of igneous activity and thrusting in Assynt: excavations at Loch Borralan. Scottish Journal of Geology, 19, 59-66.

Peach, B.N., Horne, J., Gunn, W., Clough, C.T., Hinxman, L.W. and Teall, J.J.H. (1907) The geological structure of the North-West Highlands of Scotland. Memoir of the Geological Survey of the United Kingdom.

Phemister, J. (1926) The alkaline igneous rocks of the Loch Ailsh district. In: The Geology of Strath Oykell and Lower Loch Shin (H.H. Read, J. Phemister and G. Ross, editors). Memoir of the Geological Survey of Great Britain, Sheet 102 (Scotland).

Sabine, P.A. (1952) The ledmorite dyke of Achmelvich, near Lochinver, Sutherland. Mineralogical Magazine, 29, 827-832.

Sabine, P.A. (1953) The petrography and geological significance of the post-Cambrian minor intrusions of Assynt and the adjoining districts of north-west Scotland. Quarterly Journal of the Geological Society, 109, 137-171.

Shand, S.J. (1910) On borolanite and its associates in Assynt. Transactions of the Edinburgh Geological Society, 9, part III, 202-215.

Stormer, J.C. and Nicholls, J. (1978) XLFRAC: A program for the interactive testing of magmatic differentiation models. Computers and Geoscience, 4, 143-159.
Strachan, R.A., Smith, M., Harris, A.L. and Fettes, D.J. (2002) The Northern Highland and Grampian terranes. Pp. 81-148 in: The Geology of Scotland (N.H. Trewin, editor). The Geological Society, London.

Sun, S.-S. and McDonough, W.F. (1989) Chemical and isotopic systematics of oceanic basalts: implications for mantle compositions and processes. P. 313-347 in: Magmatism in the Ocean Basins (A.D. Saunders and M.J. Norry, editors). Special Publication No. 42, Geological Society of London.

Teall, J.J.H. (1900) On nepheline-syenite and its associates in the North-west of Scotland. Geological Magazine, 7, 385-392.

Teall, J.J.H. (1907) Post-Cambrian igneous rocks of older date than the great thrust-movements of the region: their petrography. Pp. 440-452 in: The Geological Structure of the North-West Highlands of Scotland (B.N. Peach, J. Horne, W. Gunn, C.T. Clough, L.W. Hinxman and J.J.H. Teall, editors). Memoir of the Geological Survey of the United Kingdom.

Thirlwall, M.F. and Burnard, P. (1990) Pb-Sr-Nd isotope and chemical study of the origin of undersaturated and oversaturated shoshonitic magmas from the Borralan pluton, Assynt, NW Scotland. Journal of the Geological Society, 147, 259-269.

Thompson, R.N. and Fowler, M.B. (1986) Subductionrelated shoshonitic and ultrapotassic magmatism: a study of Siluro-Ordovician syenites from the Scottish Caledonides. Contributions to Mineralogy and Petrology, 94, 507-522.

Van Breemen, O., Aftalion, M. and Johnson, M.R.W. (1979) Age of the Loch Borrolan Complex, Assynt, and late movements along the Moine Thrust Zone. Journal of the Geological Society, 136, 489-495.

Woolley, A.R. (1970) The structural relationships of the Loch Borrolan Complex, Scotland. Geological Journal, 7, 171-182.

Young, B.N. (1989) The petrology and petrogenesis of a suite of minor alkaline intrusions in the Assynt District, Sutherland. Unpublished $\mathrm{PhD}$ thesis, University of Aberdeen.

Young, B.N., Parsons, I. and Threadgould, R. (1994) Carbonatite near the Loch Borralan intrusion, Assynt. Journal of the Geological Society, 151, 945-954.

[Manuscript received 8 April 2004: revised 29 June 2004] 